\title{
PENGARUH PEMBERIAN MADU TERHADAP GAMBARAN HITUNG LEUKOSIT PADA MENCIT YANG TERINFEKSI SALMONELLA TYPHI
}

\author{
Andi Muhammad Faisal Ansar', Nadyah Haruna ${ }^{2}$, Andi Tihardimanto ${ }^{3}$ \\ 1,2,3 Program Studi Pendidikan Dokter UIN Alauddin Makassar \\ Email: ${ }_{1}^{1}$ andifaisalansar40@gmail.com
}

\begin{abstract}
Abstrak
Demam tifoid merupakan infeksi sistemik yang disebabkan oleh Salmonella typhi dan madu memiliki aktivitas antibakteri. Tujuan penelitian ini untuk mengetahui apakah terdapat perubahan jumlah hitung leukosit pada hewan coba yang terinfeksi Salmonella typhi setelah pemberian madu. Penelitian ini menggunakan 24 ekor mencit betina (Mus musculus) berumur 2-3 bulan dengan berat badan 20 - 30 gram yang diinjeksikan bakteri Salmonella typhi dengan pengenceran $10^{3} \mathrm{CFU}$. Kemudian dibagi menjadi 4 kelompok yaitu mencit yang diberikan aquades $0,5 \mathrm{ml} / 20 \mathrm{gBB} / \mathrm{hari}$, dan madu dengan dosis $0,04 \mathrm{ml} / 20 \mathrm{gBB} /$ hari, $0,06 \mathrm{ml} / 20 \mathrm{gBB} /$ hari, dan dosis $0,08 \mathrm{ml} / 20 \mathrm{gBB} /$ hari. Hasil penelitian menunjukkan bahwa setelah pemberian madu, terjadi penurunan jumlah hitung leukosit mencit pada mencit yang terinfeksi Salmonella typhi dimana penurunan jumlah hitung leukosit terbanyak pada kelompok 4 yakni $7.21 \times 10^{3} / \mu \mathrm{L}$, diikuti kelompok 3 dengan $8.81 \times 10^{3} / \mu \mathrm{L}$, lalu kelompok 2 dengan 9.18.x103/ $\mu \mathrm{L}$, dan kelompok 1 dengan $9.33 \times 10^{3} / \mu \mathrm{L}$. Pada uji t paired diperoleh nilai $\mathrm{t}>2.068(\mathrm{t}=9,958)$, lalu uji ANOVA didapatkan nilai $\mathrm{p}>0,05(\mathrm{p}=0.179)$ dan dilanjutkan dengan uji pengelompokkan yaitu uji LSD. Hasil yang didapatkan adalah kelompok 1, 2, 3, dan 4 secara umum terjadi penurunan jumlah hitung leukosit pada mencit yang terinfeksi Salmonella typhi tapi tidak signifikan antar kelompok. Kesimpulan penelitian ini ialah pemberian madu dapat menurunkan jumlah hitung leukosit pada mencit yang terinfeksi Salmonella typhi.
\end{abstract}

Kata Kunci: madu, leukosit, Salmonella typhi

\section{Pendahuluan}

Demam tifoid merupakan infeksi sistemik yang disebabkan oleh Salmonella typhi, yang biasanya terkontaminasi pada makanan dan minuman yang dikonsumsi. Penyakit akut ditandai oleh demam lama, sakit kepala, mual, tidak nafsu makan, dan konstipasi atau kadang-kadang diare. Gejala seringkali tidak spesifik dan sulit dibedakan dengan penyakit demam lainnya, namun tingkat keparahan klinis bervariasi dan kasus yang parah dapat menyebabkan komplikasi atau bahkan kematian. Kejadian ini utamanya berhubungan dengan sanitasi yang buruk dan kurangnya minum air bersih (WHO, 2018).

Salmonella typhi sebagai penyebab demam tifoid harus dilemahkan atau dimatikan. Pengobatan konvensional yang banyak dilakukan untuk demam tifoid adalah dengan pemberian antibiotik oral (Mubasyiroh, 2010), Beberapa alternatif yang mungkin dapat diberikan pada pasien demam tifoid karena khasiatnya seperti madu, madu memiliki aktivitas antibakteri dikarenakan beberapa faktor, seperti: tekanan osmotik, keasaman, hidrogen peroksida (Nurheti, 2015), zat lain seperti lisozom, asam fenolik dan flavonoid juga terdapat dalam madu yang diketahui dapat menghambat bakteri gram positif dan gram negatif (Ali, 2013), hal inilah yang mendorong penelitian mulai diarahkan untuk mencari alternatif terapi juga terkait meningkatkan imunitas dalam mengobati demam tifoid.

Menurut Sukmawati (2008), Pengaruh Madu Lebah (Apis melifera) Terhadap Jumlah Sel Darah Putih Pada Radang Luka Gores Pada Mencit (Mus musculus) BALB/CF 
JANTAN, menyimpulkan Madu Lebah (Apis melifera) berpengaruh Terhadap penurunan Jumlah Sel Darah Putih Pada Radang Luka Gores Pada Mencit (Mus musculus). Sedangkan pada penelitian ini perlakuan yang diberikan ialah madu hutan Apis dorsata dan sampel yang digunakan ialah darah mencit yang terinfeksi Salmonella typhi.

Tujuan penelitian ini untuk mengetahui apakah terdapat perubahan jumlah hitung leukosit pada hewan coba yang terinfeksi Salmonella typhi setelah pemberian madu.

\section{Bahan dan Metode}

Penelitian dilakukan di Laboratorium Penelitian Program Studi Pendidikan Dokter Fakultas Kedokteran dan Ilmu Kesehatan Universitas Islam Negeri Alauddin Makassar, J1. Sultan Alauddin no. 63, Makassar, Sulawesi Selatan. Populasi penelitian ini merupakan keseluruhan objek penelitian. Populasi dari penelitian ini adalah mencit (Mus Musculus) betina dan sampel yang digunakan dalam penelitian ini ialah serum darah mencit betina hasil perlakuan, kemudian diperiksa jumlah hitung jenis leukositnya.

Penelitian ini dilakukan di Laboratorium Program Studi Pendidikan Dokter UIN Alauddin Makassar selama 3 minggu. Penelitian ini merupakan penelitian eksperimen dengan pendekatan pre test and post test with control group design. Populasi pada penelitian ini adalah mencit betina (Mus musculus), sampel yang digunakan adalah serum darah mencit betina hasil perlakuan, kemudian diperiksa hitung jenis leukositnya dengan kriteria inklusi berjenis kelamin betina, darah mencit positif Salmonella typhi, usia mencit sekitar 2-3 bulan dengan berat badan antara 20-30 gram, serta mencit yang akan digunakan darahnya telah melalui tahapan adaptasi. Besar sampel yang digunakan sebanyak 24 ekor yang dibagi menjadi 4 kelompok perlakuan, yaitu kelompok kelompok 1 merupakan kontrol, kelompok 2 perlakuan dengan madu dosis 0,04 $\mathrm{ml} / 20 \mathrm{gBB} /$ hari gr, kelompok 3 perlakuan dengan madu dosis $0,06 \mathrm{ml} / 20 \mathrm{gBB} / \mathrm{hari}$, dan kelompok 4 perlakuan dengan madu dosis 0,08 $\mathrm{ml} / 20 \mathrm{gBB} /$ hari. Proses penelitian ini dimulai dari adaptasi selama 1 minggu, lalu dilakukan pengelompokkan dan dilakukan pengukuran leukosit total, lalu mencit diinjeksikan Salmonella typhi $10^{3} \mathrm{CFU}$, setelah terinfeksi dilakukan kembali pengukuran leukosit, kemudian dilakukan pemberian madu selama 1 minggu sesuai dengan kelompoknya masingmasing dan dilakukan kembali pengukuran leukosit. Data yang didapatkan kemudian diolah dengan menggunakan Statistical Package Social Science (SPSS) for windows dengan uji normalitas dengan menggunakan uji Kolmogrov-smirnov. Apabila data berdistribusi normal maka akan digunakan uji t paired dan jika data tidak berdistribusi normal maka akan digunakan uji wilcoxon. Apabila hasil sesuai dengan taraf signifikansi yaitu $\mathrm{p}>0,05$, maka dilanjutkan dengan uji One Way ANOVA dan dilanjutkan dengan uji lanjut pengelompokan LSD. 


\section{Hasil Penelitian}

Gambar 1 menunjukan bahwa perubahan jumlah hitung leukosit berdasarkan hari pada setiap kelompok mengalami peningkatan pada hari ke 7 setelah injeksi Salmonella typhi, kemudian mengalami penurunan pada hari ke 14 setelah diberi perlakuan madu dengan dosis bertingkat. Kelompok 3 memberikan gambaran penurunan jumlah hitung leukosit paling rendah yaitu 7,22 x1000/ $\mu \mathrm{L}$ dan kelompok kontrol memberikan gambaran penurunan jumlah hitung leukosit dengan jumlah hitung leukosit paling tinggi yaitu $9,18 \times 1000 / \mu \mathrm{L}$.

Gambar 1. Rerata perubahan leukosit berdasarkan hari

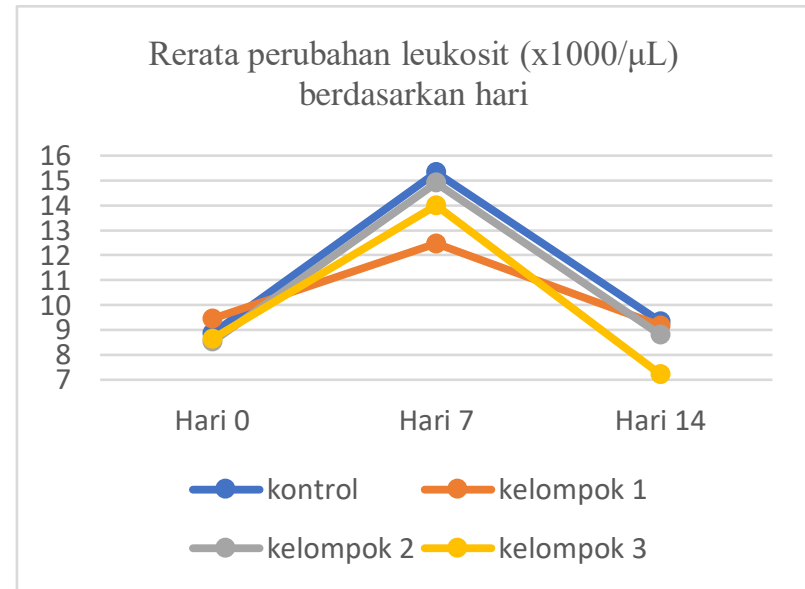

Tabel 1. menunjukan rerata jumlah hitung leukosit mencit sebelum dan setelah injeksi Salmonella typhi dari keseluruhan sampel. Rerata jumlah hitung leukosit sebelum diinjeksikan Salmonella typhi yakni 8,86 $\mathrm{x} 1000 / \mu \mathrm{L}$ dan setelah diinjeksikan Salmonella typhi jumlah hitung leukosit menjadi 14,17 $\mathrm{x} 1000 / \mu \mathrm{L}$. Dari hasil analisis uji $\mathrm{t}$ paired diperoleh bahwa nilai absolut $t$ hitung sebesar 7,423 dan nilai t tabel $(\alpha=0,05 ; \mathrm{df}=23)$ sebesar
2,068, dimana nilai absolut t hitung lebih besar dari nilai t tabel $(7,423>2,068)$ sedemikian sehingga terdapat peningkatan yang signifikan pada jumlah hitung leukosit darah mencit sebelum dan sesudah diinjeksikan Salmonella typhi. Hal tersebut sejalan dengan nilai p yang diberikan pada tabel 4.6, dimana nilai $p$ sebesar 0,000 lebih kecil dari taraf signifikansi 0,05 yang menunjukan terdapat peningkatan yang signifikan pada jumlah hitung leukosit mencit setelah injeksi Salmonella typhi.

Tabel 1. Perbedaan rerata jumlah hitung leukosit mencit sebelum dan setelah injeksi Salmonella typhi

\begin{tabular}{ccccc}
\hline & Rerata & $\begin{array}{c}\text { Standar } \\
\text { deviasi }\end{array}$ & $\begin{array}{c}\text { Nilai } \\
\mathrm{t}\end{array}$ & Nilai p \\
\hline $\begin{array}{c}\text { Sebelum } \\
\text { injeksi } \\
\text { Salmonella } \\
\text { typhi }\end{array}$ & 8,86 & 1,44 & & \\
$\begin{array}{c}\text { Setelah } \\
\text { injeksi }\end{array}$ & & & 7,423 & 0,000 \\
$\begin{array}{c}\text { Salmonella } \\
\text { typhi }\end{array}$ & 14,17 & 2,71 & & \\
\hline \multicolumn{5}{c}{ Sumber: Data diolah (2020) }
\end{tabular}

Tabel 2. menunjukan rerata jumlah hitung leukosit mencit sebelum dan setelah pemberian madu dari keseluruhan sampel. Rerata jumlah hitung leukosit sebelum pemberian madu yakni $14,17 \times 1000 / \mu \mathrm{L}$ dan setelah pemberian madu jumlah hitung leukosit menjadi 8,63 x1000/ $\mu$ L. Dari hasil analisis uji $\mathrm{t}$ paired diperoleh bahwa nilai absolut t hitung sebesar 9,958 dan nilai t tabel $(\alpha=0,05 ; \mathrm{df}=23)$ sebesar 2,068 , dimana nilai absolut $\mathrm{t}$ hitung lebih besar dari nilai $\mathrm{t}$ tabel $(9,958>2,068)$ sedemikian sehingga terdapat penurunan yang signifikan pada jumlah hitung leukosit darah mencit sebelum dan sesudah pemberian madu. Hal tersebut sejalan dengan 
nilai $\mathrm{p}$ yang diberikan pada tabel 4.7 , dimana nilai $\mathrm{p}$ sebesar 0,000 lebih kecil dari taraf signifikansi 0,05 yang menunjukan terdapat penurunan yang signifikan pada jumlah hitung leukosit mencit setelah pemberian madu.

Tabel 2. Perbedaan rerata jumlah hitung leukosit mencit sebelum dan setelah pemberian madu

\begin{tabular}{ccccc}
\hline & Rerata & $\begin{array}{c}\text { Standar } \\
\text { deviasi }\end{array}$ & $\begin{array}{c}\text { Nilai } \\
\mathrm{t}\end{array}$ & Nilai p \\
\hline $\begin{array}{c}\text { Sebelum } \\
\text { pemberian } \\
\text { madu }\end{array}$ & 14,17 & 2,17 & & \\
$\begin{array}{c}\text { Setelah } \\
\text { pemberian } \\
\text { madu }\end{array}$ & 8,63 & 1,86 & & \\
\hline
\end{tabular}

\section{Sumber: Data diolah (2020)}

Pada tabel 3, untuk kelompok pemberian madu dapat dilihat pada hari terakhir perlakuan nilai rerata jumlah hitung leukosit 8,63 x1000/ $\mu \mathrm{L}$ dan hari pertama 14,17 $\mathrm{x} 1000 / \mu \mathrm{L}$ sehingga diketahui selisihnya $-5,54$. Selisih tersebut cukup besar sehingga terdapat perbedaan yang signifikan dari rerata hari pertama dan hari terakhir.

Untuk kelompok kontrol (Tanpa pemberian madu) didapatkan rerata pada hari terakhir penelitian nilai rerata jumlah hitung leukosit $9,33 \times 1000 / \mu \mathrm{L}$ dan hari pertama 15,31 x1000/ $\mu$ L sehingga selisihnya 5,98. Selisih ini terbilang kecil sehingga tidak teradapat perbedaan yang signifikan dari rerata hari pertama dan hari terakhir.

Tabel 3. Selisih perbedaan rerata jumlah hitung leukosit dengan hari pertama

\begin{tabular}{ccccc}
\hline Kelompok & $\boldsymbol{t}_{\boldsymbol{0}}$ & $\boldsymbol{t}_{\boldsymbol{1}}$ & $\boldsymbol{t}_{\boldsymbol{1}-\boldsymbol{t}_{\boldsymbol{0}}}$ & Nilai P \\
\hline Pemberian & 14,17 & 8,63 & $-5,54$ & 0,000 \\
Madu & & & & \\
& & & & \\
Tanpa & & & & \\
Pemberian & & & & \\
Madu & & & & \\
\hline
\end{tabular}

$$
15,31 \quad 9,33 \quad-5,98 \quad 0,017
$$

Sumber: Data diolah (2020)

Keterangan: $\quad t_{0}=$ jumlah hitung leukosit sebelum pemberian madu

(hari pertama setelah injeksi Salmonella typhi) $t_{l}=$ jumlah hitung leukosit setelah pemberian madu

Tabel 4. menunjukan rerataan dari jumlah hitung leukosit mencit. Hasil menunjukan bahwa jumlah hitung leukosit mencit terus menurun ketika penambahan dosis madu juga ditambah sampai perlakuan terakhir di kelompok 3. Pada perlakuan kontrol jumlah hitung leukosit tertinggi sebesar $9,33 \times 1000 / \mu \mathrm{L}$.

Tabel 4. Rata-rata jumlah hitung leukosit mencit setelah perlakuan hari terakhir

\begin{tabular}{cccc}
\hline Perlakuan & $\mathbf{N}$ & $\begin{array}{c}\text { Rerataan } \\
(\mathbf{x 1 0 0 0 / \mu L )}\end{array}$ & $\begin{array}{c}\text { Standar } \\
\text { Deviasi }\end{array}$ \\
\hline Kontrol & 6 & 9,33 & 1,50 \\
Kelompok 1 & 6 & 9,18 & 2,88 \\
Kelompok 2 & 6 & 8,81 & 0,87 \\
Kelompok 3 & 6 & 7,21 & 1,12 \\
\hline
\end{tabular}

Sumber: Data diolah (2020)

Tabel 5. menunjukan uji one way anova jumlah hitung leukosit pada mencit. Hasil menunjukan bahwa pemberian perlakuan berupa kontrol, kelompok 1, kelompok 2, dan kelompok 3 tidak memiliki pengaruh yang bermakna pada jumlah hitung leukosit mencit. Hal tersebut dikarenakan nilai $\mathrm{P}$ sebesar 0,179 >0,05. Untuk mengetahui perbedaan antar perlakuan maka selanjutnya dilakukan uji LSD.

Tabel 5. Hasil analisis one way anova jumlah hitung leukosit mencit

\begin{tabular}{ccccc}
\hline Perlakuan & $\mathbf{N}$ & $\begin{array}{c}\text { Rerataan } \\
(\mathbf{x 1 0 0 0 / \mu L )})\end{array}$ & $\begin{array}{c}\text { Standar } \\
\text { Deviasi }\end{array}$ & $\begin{array}{c}\text { Nilai } \\
\mathbf{P}\end{array}$ \\
\cline { 1 - 4 } Kontrol & 6 & 9,33 & 1,50 & \\
$\begin{array}{c}\text { Kelompok } \\
1\end{array}$ & 6 & 9,18 & 2,88 & 0,179 \\
$\begin{array}{c}\text { Kelompok } \\
2\end{array}$ & 6 & 8,81 & 0,87 & \\
\hline
\end{tabular}


Kelompok 6

7,21

1,12

*uji one way anova : Nilai $\mathrm{p}<0,05$;

terdapat perbedaan bermakna

Tabel 6. menunjukan hasil uji LSD pada jumlah hitung leukosit pada mencit. Hasil menunjukan keseluruhan perlakuan tidak memiliki perbedaan yang bermakna antar perlakuan, hal tersebut karena kedua nilai $\mathrm{p}$ nilai $\mathrm{p}$ keseluruhan lebih besar dari 0,05 (nilai $\mathrm{p}>0,05)$. Tetapi secara umum terdapat penurunan leukosit pada setiap kelompok.

Tabel 6. Hasil LSD jumlah hitung leukosit total pada mencit

\begin{tabular}{ccccc}
\hline Perlakuan & \multicolumn{5}{c}{$\boldsymbol{\alpha}=\mathbf{0 , 0 5}$} \\
& $\mathbf{1}$ & $\mathbf{2}$ & $\mathbf{3}$ & $\mathbf{4}$ \\
\hline 1. Kontrol & - & & \\
2. Kelompok 1 & 0,885 & - & & \\
3. Kelompok 2 & 0,619 & 0,724 & - & \\
4. Kelompok 3 & 0,052 & 0,069 & 0,134 & - \\
\hline *Uji LSD: Nilai P < 0,05 terdapat perbedaan \\
\multicolumn{5}{c}{ makna antar perlakuan }
\end{tabular}

\section{Pembahasan}

Pada pemeriksaan jumlah hitung leukosit pasien demam tifoid terdapat gambaran leukopeni (+ 3000-8000 per mm), limfositosis relatif, monositosis, aneosinofilia dan trombositopenia ringan. Terjadinya leukopenia akibat depresi sumsum tulang oleh endotoksin dan mediator endogen yang ada. Diperkirakan kejadian leukopenia 25\%, Namun banyak laporan bahwa dewasa ini hitung leukosit kebanyakan dalam batas normal atau leukositosis ringan. Kejadian trombositopenia sehubungan dengan produksi yang menurun dan destruksi yang meningkat oleh sel-sel RES. Sedangkan anemia juga disebabkan produksi hemoglobin yang menurun serta kejadian perdarahan intestinal yang tak nyata (occult bleeding). Perlu di waspadai bila terjadi penurunan hemoglobin secara akut pada minggu ke 34, yang bisanya disebabkan oleh perdarahan hebat dalam abdomen.

Tabel 1. menunjukan rerata jumlah hitung leukosit mencit sebelum dan setelah injeksi Salmonella typhi dari keseluruhan sampel. Rerata jumlah hitung leukosit sebelum diinjeksikan Salmonella typhi yakni 8,86 $\mathrm{x} 1000 / \mu \mathrm{L}$ dan setelah diinjeksikan Salmonella typhi jumlah hitung leukosit menjadi 14,17 $\mathrm{x} 1000 / \mu \mathrm{L}$. Dari hasil analisis uji $\mathrm{t}$ paired diperoleh bahwa nilai absolut $t$ hitung sebesar 7,423 dan nilai t tabel $(\alpha=0,05 ; \mathrm{df}=23)$ sebesar 2,068, dimana nilai absolut t hitung lebih besar dari nilai t tabel $(7,423>2,068)$ sedemikian sehingga terdapat peningkatan yang signifikan pada jumlah hitung leukosit darah mencit sebelum dan sesudah diinjeksikan Salmonella typhi. Hal tersebut sejalan dengan nilai p yang diberikan pada tabel 4.6, dimana nilai $\mathrm{p}$ sebesar 0,000 lebih kecil dari taraf signifikansi 0,05 yang menunjukan terdapat peningkatan yang signifikan pada jumlah hitung leukosit mencit setelah injeksi Salmonella typhi.

Peningkatan jumlah leukosit dalam sirkulasi merupakan tanda terjadinya peradangan dalam tubuh termasuk peradangan yang disebabkan oleh infeksi bakteri seperti Salmonella typhi. Pada pemeriksaan hitung lekosit total pasien demam tifoid terdapat gambaran leukopeni (+ 3000-8000 per mm), limfositosis relatif, monositosis, aneosinofilia 
dan trombositopenia ringan. Terjadinya leukopenia akibat depresi sumsum tulang oleh endotoksin dan mediator endogen yang ada. Diperkirakan kejadian leukopenia 25\%, Namun banyak laporan bahwa dewasa ini hitung leukosit kebanyakan dalam batas normal atau leukositosis ringan.

Tabel 2 menunjukan rerata jumlah hitung leukosit mencit sebelum dan setelah pemberian madu dari keseluruhan sampel. Rerata jumlah hitung leukosit sebelum pemberian madu yakni $14,17 \times 1000 / \mu \mathrm{L}$ dan setelah pemberian madu jumlah hitung leukosit menjadi 8,63 x1000/ $\mu$ L. Dari hasil analisis uji t paired diperoleh bahwa nilai absolut thitung sebesar 9,958 dan nilai t tabel $(\alpha=0,05 ; \mathrm{df}=23)$ sebesar 2,068 , dimana nilai absolut $\mathrm{t}$ hitung lebih besar dari nilai $\mathrm{t}$ tabel $(9,958>2,068)$ sedemikian sehingga terdapat penurunan yang signifikan pada jumlah hitung leukosit darah mencit sebelum dan sesudah pemberian madu. Hal tersebut sejalan dengan nilai $\mathrm{p}$ yang diberikan pada tabel 2 , dimana nilai $\mathrm{p}$ sebesar 0,000 lebih kecil dari taraf signifikansi 0,05 yang menunjukan terdapat penurunan yang signifikan pada jumlah hitung leukosit mencit setelah pemberian madu.

Hal ini sejalan dengan manfaat madu sebagai antibakteri dan antiinflamasi. Madu memiliki efek antimikroba. Faktor-faktor yang membuat madu memiliki fungsi antibakteri adalah tingkat keasaman, tekanan osmotic madu, hidrogen peroksida, asam aromatik, dan fenol (Suranto, 2007). Nanoperoksida juga memberikan efek antibakteri pada madu.
Komponen fenolik lain dari nektar juga memiliki aktivitas antioksidan selain diketahui menghambat bakteri Gram-positif dan Gramnegatif (Stagos 2018).

Antiinflamasi, madu dapat mengurangi inflamasi dan edema karena mempunyai sifat antiinflamasi yang juga berasal dari flavonoid6. Flavonoid dapat menjadi zat antiinflamasi dan penstabil Reactive Oxygen Species (ROS). Efek flavonoid sebagai antioksidan secara tidak langsung mendukung efek antiinflamasi flavonoid. Adanya radikal bebas dapat menarik berbagai mediator inflamasi dan flavonoid dapat menstabilkan ROS dengan bereaksi dengan senyawa reaktif dari radikal sehingga radikal menjadi inaktif (Waleed, 2015).

Pada tabel 3 diatas untuk kelompok pemberian madu dapat dilihat pada hari terakhir perlakuan nilai rerata jumlah hitung leukosit $8,63 \times 1000 / \mu \mathrm{L}$ dan hari pertama 14,17 x1000/ $\mu \mathrm{L}$ sehingga diketahui selisihnya -5,54. Selisih tersebut cukup besar sehingga terdapat perbedaan yang signifikan dari rerata hari pertama dan hari terakhir.

Untuk kelompok kontrol (Tanpa pemberian madu) didapatkan rerata pada hari terakhir penelitian nilai rerata jumlah hitung leukosit $9,33 \times 1000 / \mu \mathrm{L}$ dan hari pertama 15,31 $\mathrm{x} 1000 / \mu \mathrm{L}$ sehingga selisihnya 5,98 . Selisih ini terbilang kecil sehingga tidak teradapat perbedaan yang signifikan dari rerata hari pertama dan hari terakhir.

Hal ini sesuai dengan penelitian milik Irianto (Irianto, 2014) yang mengatakan 
gambaran abnormal pemeriksaan hematologi yang sering ditemukan pada penderita demam tifoid yaitu penurunan jumlah leukosit (leukopenia) terlihat pada pasien penderita demam tifoid saat 2 minggu pertama sakit dimana jumlah leukosit berkisar antara 4.0006.000/mm3 dan terjadi penurunan kembali pada 2 minggu berikutnya hingga 3.000$5.000 / \mathrm{mm} 3$. Penyebab penurunan jumlah leukosit total pada kelompok kontrol lebih tinggi dibandingkan dengan kelompok yang diberikan madu karena adanya depresi pada sumsum tulang yang dilakukan oleh endotoksin dan mediator endogen yang dimiliki oleh Salmonella typhi, selain itu invasi dari bakteri Salmonella typhi ke organorgan haemopoetik seperti kelenjar getah bening, spleen, tonsil, sumsum tulang belakang yang juga menjadi penyebab penekanan laju haematopoesis (Natari, Rosinta, 2014) Sedangkan pada kelompok dengan pemberian madu memiliki selisih yang lebih sedikit disebabkan karena madu memiliki kandungan anti bakteri dan antiinflamasi sehingga dapat mengurangi depresi pada sumsum tulang.

Tabel 4 menunjukan rerataan dari jumlah hitung leukosit mencit. Hasil menunjukan bahwa jumlah hitung leukosit mencit terus menurun ketika penambahan dosis madu juga ditambah sampai perlakuan terakhir di kelompok 3. Pada perlakuan kontrol jumlah hitung leukosit tertinggi sebesar $9,33 \times 1000 / \mu \mathrm{L}$.
Tabel 5 menunjukan uji one way anova jumlah hitung leukosit pada mencit. Hasil menunjukan bahwa pemberian perlakuan berupa kontrol, kelompok 1, kelompok 2, dan kelompok 3 tidak memiliki pengaruh yang bermakna pada jumlah hitung leukosit. Hal tersebut dikarenakan nilai $\mathrm{P}$ sebesar 0,179 > 0,05 . Untuk mengetahui perbedaan antar perlakuan maka selanjutnya dilakukan uji LSD.

Tabel 6 menunjukan hasil uji LSD pada jumlah hitung leukosit pada mencit. Hasil menunjukan keseluruhan perlakuan tidak memiliki perbedaan yang bermakna antar perlakuan, hal tersebut karena kedua nilai $\mathrm{p}$ nilai $\mathrm{p}$ keseluruhan lebih besar dari 0,05 (nilai p >0,05). Tetapi secara umum terdapat penurunan jumlah hitung leukosit pada setiap kelompok.

Hal ini sejalan dengan manfaat madu sebagai antibakteri dan antiinflamasi. Madu memiliki efek antimikroba. Faktor-faktor yang membuat madu memiliki fungsi antibakteri adalah tingkat keasaman, tekanan osmotic madu, hidrogen peroksida, asam aromatik, dan fenol1. Nanoperoksida juga memberikan efek antibakteri pada madu. Komponen fenolik lain dari nektar juga memiliki aktivitas antioksidan selain diketahui menghambat bakteri Grampositif dan Gram-negatif (Stagos, 2018).

Keasaman berpengaruh pada pertumbuhan dan kelangsungan hidup bagi sel bakteri. Dengan keasaman yang tinggi, jumlah konsentrasi ion hidrogen juga akan meningkat, yang akan mengganggu gradien transmembran 
proton dari sel bakteri. Kemudian, sel akan membawa proton melewati pompa proton yang memicu kehilangan energi dan penurunan $\mathrm{pH}$. $\mathrm{H}+$ yang ada akan membuat Struktur pada permukaan sel, dinding sel, membran sitoplasma, dan periplasma terbuka dan mempengaruhi ikatan ion makromolekul yang dapat mengganggu struktur tiga dimensi dan beberapa fungsi. Pada $\mathrm{pH}<5$, molekul yang tidak dipisahkan oleh beberapa asam bisa sangat tinggi, kemudian menjadi lipofilik yang memungkinkan untuk masuk dengan mudah melewati membran. Nilai $\mathrm{pH}$ yang rendah ini juga akan berpengaruh pada komponen sel lalu merusak struktur (dengan mengganggu ikatan ionik). Perubahan ini dapat membuat terganggunya transportasi nutrisi dan pembaruan energy (Ray, 2013).

Faktor selanjutnya adalah madu juga mengandung senyawa yang disebut fenol yang memiliki sifat antibakteri. Senyawa fenol ini sangat bermacam seperti: 1,4dihydroxybenzene, asam syringat, benzyl alkohol, metil syringate, pinocembrin, terpene, dan flavonoid. Aktivitas antibakteri fenol adalah dengan, merusak dan menembus dinding sel, meracuni protoplasma sel, mengendapkan protein dari sel bakteri, mendenaturasi enzim dan atau asam amino yang membantu germinasi spora. Komponen fenolik bermolekul besar mampu menginaktifkan enzim esensial di dalam sel mikroba meskipun pada konsentrasi yang sangat rendah (Stagos, 2018).
Pada salah satu penelitian terkait aktivitas antibakteri berbagai jenis madu didapatkan bahwa madu hutan memiliki aktivitas antibakteri paling baik diantara yang lainnya (Hollong, 2015).

Antiinflamasi, madu dapat mengurangi inflamasi dan edema karena mempunyai sifat antiinflamasi yang juga berasal dari flavonoid6. Flavonoid dapat menjadi zat antiinflamasi dan penstabil Reactive Oxygen Species (ROS). Efek flavonoid sebagai antioksidan secara tidak langsung mendukung efek antiinflamasi flavonoid. Adanya radikal bebas dapat menarik berbagai mediator inflamasi dan flavonoid dapat menstabilkan ROS dengan bereaksi dengan senyawa reaktif dari radikal sehingga radikal menjadi inaktif (Waleed, 2015).

Madu dapat menurunkan jumlah hitung leukosit terutama PMN karena memiliki kandungan antioksidan serta zat antiinflamasi yaitu flavonoid, yang dapat menstabilkan ROS sehingga radikal bebas menjadi inaktif dan menurunkan reaksi inflamasi. Hal ini dikarenakan penurunan radikal bebas menyebabkan berkurangnya aktivasi NF- $\kappa \mathrm{B}$ dan mengakibatkan penurunan produksi IL-8 yang berperan dalam peningkatan leukosit sehingga jumlah leukosit total darah dapat menurun (Waleed, 2015).

Penelitian ini menunjukkan hasil bahwa terdapat perubahan jumlah hitung leukosit pada mencit yang terinfeksi Salmonella typhi yang mana memberikan bukti potensi bahwa madu dapat menjadi 
terapi penyakit, sebagai pembuktian kebenaran sedikit demi sedikit tentang salah satu tanda-tanda kebesaran Allah SWT dalam bentuk madu sebagaimana terwahyukan pada surah QS An-nahl/16: 69 diatas.

Kesembuhan datang setelah sebab lahiriah dan maknawi terwujud yang disertai dengan kehendak Allah. Sekian banyak yang berobat dengan obat yang sama, tetapi yang sembuh boleh jadi satu atau dua orang saja. Kadang kesembuhan seseorang lebih ditentukan oleh sejauh mana ia mengimani kemampuan obat tersebut sebagai media penyembuhan, kadang pula lebih melihat kepada sebab-sebab fisik dan maknawi pasien itu sendiri. Namun tidak dapat dipungkiri bahwa madu itu merupakan obat dari berbagai macam penyakit (Hollong, 2015).

\section{Simpulan}

Pemberian injeksi secara intraperitoneal sebanyak $10^{3} \mathrm{CFU}$ bakteri Salmonella typhi pada mencit dapat meningkatkan jumlah hitung leukosit pada mencit yang terinfeksi Salmonella typhi, dan pemberian madu dapat menurunkan jumlah hitung leukosit pada mencit yang terinfeksi Salmonella typhi secara signifikan.

\section{Daftar Pustaka}

https://www.who.int/immunization/diseases/t yphoid/en/ (diakses pada 31 juli 2019)

Dinkes Sulawesi Selatan. Profil Kesehatan Sulawesi Selatan 2014. Makassar 2015. Dinkes Kota Makassar. Laporan Penanggulangan Penderita/Kematian Penyakit Tyhpoid. Makassar 2019.
Mubasyiroh, Rofingatul. Faktor Yang Berhubungan Dengan Kejadian Diare Pada Balita Di Beberapa Iwgional Indonesia Tahun 2007. DEPKES: Puslitbang Ekologi dan Status Kesehatan Litbang Depkes. 2010.

Nurheti, Khasiat Madu Untuk Kesehatan dan Kecantikan. Yogyakarta: Rapha Publishing, 2015.

Ali Raeessi M, Aslani J, Raeessi N, Gharaie H, Karimi ZAA, Raeessi F. Honey plus coffee versus systemic steroid in the treatment of persistent post-infectious cough: A randomised controlled trial. Primary Care Respiratory Journal. 2013; 22(3), 325-30.

Shihab, M Quraish. Tafsir Al-Misbah: Pesan, Kesan dan Keserasian Al-Qur'an. Volume 15. Tangerang: PT. Lentera Hati, 2017.

Suranto, Adji, Terapi madu. Cet. I; Depok : Penebar Swadaya, 2007.

Stagos Dimitrios, Nikolaos Soulitsiotis, Christina Tsadila, Stamatina Papaeconomou, Charalampos Arvanitis, Alexandros Ntontos, Fani Karkanta, Soultana Adamou Androulaki, Konstantinos Petrotos, Demetrios A. Spandidos, Demetrios Kouretas And Dimitris Mossialos. Antibacterial and antioxidant activity of different types of honey derived from Mount Olympus in Greece. International journal of molecular medicine 42: 726-734, 2018 
Waleed K. El-Aidy, Ahmad A. Ebeid ,Abd El-

Raouf M. Sallam, Ibrahim E. Muhammad, Ayman T. Abbas, A. Kamal, Sayed Sartaj Sohrab. Evaluation of propolis, honey, and royal jelly in amelioration of peripheral blood leukocytes and lung inflammation in mouse conalbumin-induced asthma model. Saudi Journal of Biological Sciences (2015) 22,780-788

Irianto. Mikrobiologi Medis. Bandung : Alfabeta. 2013.

Natari, N. N. L., Yasa, I. W, P. S., Lestari, W. Karakteristik Penderita Demam Tifoid dengan Hasil Pemeriksaan Darah Lengkap dan Uji Widal di RSIA Bunda Periode Oktober 2013-Januari 2014. Fakultas Kedokteran Universitas Udayana. 2014.

Rosinta, L., Suryani, Y. D., \& Nurhayati, E. Hubungan Durasi Demam Dengan Kadar Leukosit pada Penderita Demam Tifoid Anak Usia 5-10 Tahun yang Dirawat Inap di Rumah Sakit Al-Ihsan Periode Januari-Desember Tahun 2014. Prosiding Pendidikan Dokter. 2014.

Ray, B. Fundamental Food Microbiologi. CRC Press: New York. Page 1996: 410-411, 402-403.

Hariyanti LF, Aktivitas Antibakteri Berbagai Jenis Madu Terhadap Antimikroba Pembusuk (Pseudomonas Fluorescens FNCC 0071 dan Pseudomonas Putida FNCC 0070).Skripsi S1 Teknologi
Pertanian. Fakultas Pertanian, Universitas Sebelas Maret: 2010.

Hollong, Hasbi Ash Shiddieqy. Madu Dalam Alquran (Kajian Tafsir Tahlili terhadap QS alNahl/16: 68-69). Universitas Islam Negeri (UIN) Alauddin Makassar. 2015 